\title{
The Impact of Drought, Normal Watering and Substrate Saturation on the Morphological and Physiological Condition of Container Seedlings of Narrow-Leaved Ash (Fraxinus angustifolia Vahl)
}

\author{
Damir Drvodelić ${ }^{1 *}$, Damir Ugarković ${ }^{1}$, Milan Oršanić ${ }^{1}$, Vinko Paulić ${ }^{1}$
}

(1) University of Zagreb, Faculty of Forestry, Department of Forest Ecology and Silviculture, Svetošimunska 25, HR-10000 Zagreb, Croatia

*Correspondence: e-mail: ddrvodelic@inet.hr

\begin{abstract}
Citation: DRVODELIĆ D, UGARKOVIĆ D, ORŠANIĆ M, PAULIĆ V 2016 The Impact of Drought, Normal Watering and Substrate Saturation on the Morphological and Physiological Condition of Container Seedlings of Narrow-Leaved Ash (Fraxinus angustifolia Vahl). South-east Eur for 7 (2): 135-142. DOI: https://doi.org/10.15177/ seefor.16-11
\end{abstract}

Received: 12 May 2016; Revised: 05 Jul 2016; Accepted: 7 Jul 2016; Published online: 19 Jul 2016

\begin{abstract}
Background and Purpose: Narrow-leaved ash (Fraxinus angustifolia Vahl) is one of the most important tree species of lowland floodplain forests in the Republic of Croatia. Recent significant climate changes, reflected in extreme temperatures and long dry periods, have had a direct impact on the dynamics and levels of groundwater, as well as on the dynamics of precipitation and floodwater, which are of decisive importance for the success of narrow-leaved ash. Our study aims to determine the morphological and physiological characteristics of seedlings of narrow-leaved ash after 72 days of drought, normal watering and substrate saturation.

Materials and Methods: The experiment was established in three treatments (drought, normal watering and saturation), and each treatment included two containers or 24 seedlings. A total of 72 seedlings were replanted. After 72 days, height growth and increment, water potential, photosynthetic efficiency and the total chlorophyll content in the leaf mesophyll were measured.

Results: Seedlings from the drought treatment wilted immediately. Seedlings saturated with water up to the root collar manifested better height and diameter growth, high water potential and a lesser physiological stress response as compared to the seedlings that were watered normally.

Conclusions: Seedlings of narrow-leaved ash, which is a hygrophytic tree species, do not tolerate dry conditions and no watering. Seedlings saturated with water for 72 days showed a better morphological-physiological status than the seedlings that received normal quantities of water.
\end{abstract}

Keywords: water potential, phytosynthetic efficiency, $\mathrm{CCl}$ index, seedling morphology, seedling physiology

\section{INTRODUCTION}

Narrow-leaved ash (Fraxinus angustifolia Vahl) is one of the most important tree species of lowland floodplain forests. In the Republic of Croatia, this tree species is found in pure stands, but more commonly mixed with other broadleaves, including pedunculate oak, black alder, lowland elm, spreading elm, poplars and other species. The basic ecological factors that determine the occurrence of this forest tree species are micro-depressions in which water is retained after frequent flooding, and clayey alluvial soil which prevents water drainage. Due to these factors, forests of narrow-leaved 
ash are exposed to long-lasting effects of surface water and high groundwater. According to Anić [1], in terms of microrelief narrow-leaved ash is the eurivalent species of floodplain forests. The habitats in which it grows range from wetland sites, where narrow-leaved ash forms a wetland forest boundary towards a swamp, to fresh micro-elevations (humid micro-elevations - "grede" in Croatian). However, it reaches its ecological optimum in wetland habitats where it faces no competition [2].

The degradation of lowland forests is a serious problem not only from a commercial and non-commercial standpoint, but also from a biological and ecological aspect. Tree decline in forest ecosystems may have different causes, such as competition between species and individuals, the effects of diverse natural phenomena (climatic excesses, thunder, wind, wet snow, icy rain, long-lasting flood, biotic factors), changes in natural ecological conditions, i.e. a drop in groundwater levels, changes in floodwater dynamics, waterlogging and drying of habitats, the pollution of flood and precipitation water), and the consequences of adverse human activity [3]. The dieback of narrow-leaved ash results from a synergy of climate change, biotic factors and anthropogenic effects on water conditions. Climate has recently undergone significant changes manifested in extreme temperatures and long dry periods that directly affect the dynamics of ground water levels and the dynamics of precipitation and floodwater, all of which are of decisive importance for the growth of narrowleaved ash. Retentions constructed in order to prevent the consequences of high water levels have exposed forests in retention areas to exceptionally high floodwater levels. Floodwater levels are much higher now than they were during flooding before the retentions were constructed. As expected, this has a negative effect on the vitality of forests in these areas. Air pollution, flooding in the vegetation period and the absence of regular winter and spring floods, coupled with consecutive dry periods, are crucial stress factors that exert an adverse impact on these forests [4-7].

This research aims to determine the following:

- Height and diameter increment $(\mathrm{mm})$ of container seedlings of narrow-leaved ash under conditions of substrate saturation and normal watering in the period from 5 May to 15 July 2015 (72 days);

- Water potential $(\Psi)$ of seedlings under conditions of substrate saturation and normal watering;

- Photosynthetic efficiency $\left(F_{v} / F_{m}\right)$ of seedling leaves under conditions of substrate saturation and normal watering;

- Total chlorophyll content of mesophyll (CCI) in the leaf of seedlings growing in saturated substrates and undernormal watering conditions;

- Correlation between diameter increment $(\mathrm{mm})$ of seedlings and their physiological condition (water potential $(\Psi)$ and the maximum quantum yield of photosystem II $\left.\left(\mathrm{F}_{\mathrm{v}} / \mathrm{F}_{\mathrm{m}}\right)\right)$;

- Correlation between the maximum quantum yield of photosytem $\left(F_{v} / F_{m}\right)$ and water potential $(\Psi)$ of normally watered seedlings.

\section{MATERIALS AND METHODS}

This research involved one-year-old seedlings of narrowleaved ash with bare roots which were replanted in 12-hole AM-POLIM multi-containers of $620 \mathrm{ml}$. Replanting was performed on 5 May 2015. The trial was established in three treatments (drought, normal watering and saturation), and each treatment included two containers or 24 seedlings. A total of 72 seedlings were replanted. The initial morphological seedling characteristics were measured prior to replanting (total height and diameter of the root collar). In the drought treatment, the seedlings were not watered during the experiment. Data on the overall monthly precipitation quantity for the meteorological station Zagreb Maksimir were used during the normal watering treatment. Watering was done with the previously determined quantity of water in $\mathrm{mm} \cdot \mathrm{m}^{-2}$. During the substrate saturation treatment, a constant water level was retained in the bath with the containers so that the water was above the seedling root collars. Seedlings from all treatments were covered in order to prevent precipitation from disrupting the experiment. Seedlings from the drought treatment died immediately after the experiment was established. On 15 July 2015, height and diameter increment were measured on the survived seedlings. The physiological properties of the seedlings (water potential, chlorophyll fluorescence "a" and the total chlorophyll content index $(\mathrm{CCl})$ in the leaf mesophyll) were also measured on the same day. The seedling water potential $(\Psi)$ was measured with a portable instrument for measuring water potential (Model 600 Pressure Chamber Instruments, Corvalis, ORE). One leaf per seedling from the tip part of the crown was selected for measurement. The measurement of chlorophyll fluorescence "a" and the determination of the maximum quantum yield of photosystem II $\left(F_{v} / F_{m}\right)$ were accomplished with a portable device FluorPen FP 100 (Photon Systems Instruments). Measurement was performed on 1 leaf in 20 seedlings from the normal watering treatment and 20 seedlings from the saturation treatment. The total chlorophyll content index was measured with a portable chlorophyll metre CCM-200 (Opti-Sciences, Tyngsboro, MA). The total chlorophyll content index was determined on the basis of five measurements per leaf on a randomly selected spot, but the main leaf vein was avoided. Under three different conditions (drought, normal watering and saturation) and two repetitions, substrate temperature $\left({ }^{\circ} \mathrm{C}\right)$ and volumetric substrate moisture (\%) were measured from 5 May to 15 July 2015. The measurements were performed every full hour using the measuring station Spectrum ( $\mathrm{N}=1705$ data). Climate data were processed with SpecWare 8 Professional software, and the data were statistically processed (descriptive statistics, ANOVA) using Statistica 7.1 software [8].

\section{RESULTS}

Table 1 shows the results of descriptive statistics of seedling height and diameter increment under substrate saturation and normal watering between 5 May 2015 and 15 July 2015. The mean height increment of narrow-leaved ash seedlings under substrate saturation conditions between 5 May 2015 and 15 July 2015 reached 110 mm (19-199 mm), 
while diameter increment amounted to $2.20 \mathrm{~mm}(9.54-4.43$ $\mathrm{mm}$ ). The mean height increment of seedlings under normal watering conditions between 5 May 2015 and 15 July 2015 amounted to $48 \mathrm{~mm}(0-119 \mathrm{~mm})$ and diameter increment amounted to $0.39 \mathrm{~mm}(0.00-1.31 \mathrm{~mm})$. A t-test was used to determine a statistically significant difference $(p=0.000033)$ in the height increment of narrow-leaved ash seedlings under substrate saturation and normal watering conditions between 5 May 2015 and 15 July 2015. The seedlings under substrate saturation conditions showed better height increment of 62 $\mathrm{mm}$ on average compared to the normally watered seedlings. A t-test was used to determine a statistically significant difference $(p=0.000000)$ in diameter increment of narrowleaved ash seedlings under substrate saturation and normal watering conditions between 5 May 2015 and 15 July 2015. Seedlings growing in saturated substrates had a diameter increment that was higher by $1.81 \mathrm{~mm}$ on average compared to normally watered seedlings.

Table 2 shows the results of descriptive statistics of the seedling water potential $(\Psi)$ under substrate saturation and normal watering conditions on 16 July 2015. The mean water potential of narrow-leaved ash seedlings under substrate saturation conditions amounted to 5.6 bar (4.4-9.0 bar), whereas under normal watering condition it was 36.1 bar (15.5- 40 bar and more). In 10 plants (45.45\%) pressure could not be taken due to instrument limitation of 40 bars. A t-test was used to determine a statistically significant difference in the water potential of narrow-leaved ash seedlings with regard to treatments $(p=0.000000)$. Seedlings that were watered needed pressure that was higher by 30.5 bars on average for water to appear on the surface of leaf cross-section. Under conditions of substrate saturation lasting for 72 days (5 May 2015 - 16 July 2015), the seedlings were under a low water stress or high water potential in relation to the seedlings that were watered, in which a low water potential or high water stress was detected.

Table 3 shows the results of descriptive statistics of the maximum quantum yield of photosytem II $\left(F_{v} / F_{m}\right)$ of seedlings under substrate saturation and normal watering conditions on 16 July 2015.The mean values of the maximum quantum yield of photosystem II $\left(F_{v} / F_{m}\right)$ in seedlings treated by substrate saturation amounted to $0.82(0.77-0.84)$, and in seedlings that were watered normally it was $0.65(0.02-0.84)$. A t-test was used to determine a statistically significant difference $(p=0.000000)$ in the success of photosynthetic efficiency of narrow-leaved ash seedlings with regard to the treatments. Watered seedlings had on average a lower maximum quantum yield of photosystem II by 0.17 . The lower the $F_{v} / F_{m}$ values are, the stronger the physiological shock of the seedlings is.

Table 4 provides the results of the descriptive statistics of the total chlorophyll content in the leaf mesophyll (CCI) of seedlings under conditions of substrate saturation and normal watering on 16 July 2015. Seedlings of narrow-leaved ash under conditions of substrate saturation had an average total chlorophyll content index (CCI) in the leaf mesophyll of 17.8 (7.8-32.6), whereas in the case of watered seedlings the above index was 18.3 (3.1-65.1) on average. The t-test results did not show the existence of a statistically significant difference $(p=0.6818)$ in the total chlorophyll content index (CCI) in the leaf mesophyll of narrow-leaved ash seedlings under conditions of substrate saturation and normal watering on 16 July 2015.

TABLE 1. Descriptive statistics of height $(\mathrm{mm})$ and diameter $(\mathrm{mm})$ increment of container seedlings of narrow-leaved ash (Fraxinus angustifolia Vahl) under conditions of substrate saturation and normal watering between 5 May 2015 and 15 July 2015

\begin{tabular}{lccccccccc}
\hline \multicolumn{1}{c}{ Variable } & N & Treatment & Mean & Median & Minimum & Maximum & Variance & Std. Dev. \\
\hline Height increment $(\mathrm{mm})$ & \multirow{2}{*}{24} & Saturation & 110 & 121 & 19 & 199 & 3203 & 57 \\
Diameter increment $(\mathrm{mm})$ & & & 2.20 & 2.12 & 0.54 & 4.43 & 0.79 & 0.89 \\
\hline Height increment $(\mathrm{mm})$ & \multirow{2}{*}{24} & \multirow{2}{*}{ Watering } & 48 & 46 & 0 & 119 & 845 & 29 \\
Diameter increment $(\mathrm{mm})$ & & & 0.39 & 0.33 & 0.00 & 1.31 & 0.17 & 0.42 \\
\hline
\end{tabular}

TABLE 2. Descriptive statistics of the seedling water potential $(\Psi)$ under substrate saturation and normal watering conditions on 16 July 2015.

\begin{tabular}{lccccccc}
\hline \multicolumn{1}{c}{ Treatment } & N & Mean & Median & Minimum & Maximum & Variance & Std. Dev. \\
\hline Saturation & 24 & 5.6 & 5.4 & 4.4 & 9.0 & 1.3 & 1.1 \\
Watering & 22 & 36.1 & 39.5 & 15.5 & 40.0 & 36.7 & 6.1 \\
\hline
\end{tabular}

TABLE 3. Descriptive statistics of the maximum quantum yield of photosytem II (Fv/Fm) of seedlings under substrate saturation and normal watering conditions on 16 July 2015

\begin{tabular}{lcccccccc}
\hline \multicolumn{1}{c}{ Treatment } & N & Mean & Median & Minimum & Maximum & Variance & Std. Dev. \\
\hline Saturation & 20 & 0.82 & 0.83 & 0.77 & 0.84 & 0.00 & 0.02 \\
Watering & 20 & 0.65 & 0.73 & 0.02 & 0.84 & 0.04 & 0.20 \\
\hline
\end{tabular}


A negative and significant correlation ( $r=-0.4507)$ was found between diameter increment $(\mathrm{mm})$ of narrow-leaved ash seedlings under conditions of substrate saturation and water potential (bar) on 16 July 2015 (Figure 1).

A positive and significant correlation $(r=0.40762)$ was observed between diameter increment $(\mathrm{mm})$ of narrowleaved ash seedlings under conditions of normal watering and maximum quantum yield of photosystem II $\left(\mathrm{F}_{\mathrm{v}} / \mathrm{F}_{\mathrm{m}}\right)$ of seedlings on 16 July 2015 (Figure 2).

A negative and significant correlation ( $r=-0.4195)$ was found between the maximum quantum yield of photosystem II $\left(F_{v} / F_{m}\right)$ and water potential (bar) in normally watered seedlings on 16 July 2015 (Figure 3).

Table 5 presents descriptive statistics of the analyzed microclimatic elements. The differences between the minimal and maximal values, i.e. maximal oscillations in substrate temperature in dry conditions amounted to $24.2^{\circ} \mathrm{C}$, in saturated conditions to $15.9^{\circ} \mathrm{C}$, and in normal conditions to $23.7^{\circ} \mathrm{C}$. Absolute oscillations in the values of volumetric soil moisture reached $27.5 \%$ in dry conditions, $112.1 \%$ in saturated conditions, and $27.6 \%$ in normal conditions.

According to the results in Table 6, significant differences were found in mean values of substrate temperature and volumetric substrate moisture for the observed cases of drought, saturation and normal watering.

\section{DISCUSSION}

According to Hrašovec et al. [9], drought has an important effect on the growing intensity of narrow-leaved ash dieback. If water supply is poor, then important physiological processes are decreased or halted, which affects plant growth [10].

In our research, seedlings under drought treatment died very soon after the establishment of the experiment. Seedling mortality can be explained by the biological properties of narrow-leaved ash (hygrophyte) and by adverse ecological conditions (lack of moisture in the soil and extremely high substrate temperature inside the containers). During flooding, the air in soil pores is replaced by water, which leads to oxygen concentrations that are 30 times lower than those in aerated soils [11]. Because the seedling root collars were submerged in water all of the time, hypertrophic lenticels were developed, while adventitious roots on the bottom part of the stem did not grow. Jaeger also reached the same result [12]. The European ash covered by floods during the entire vegetation

TABLE 4. Descriptive statistics of the total chlorophyll content in the leaf mesophyll (CCI) of container seedlings of narrow-leaved ash (Fraxinus angustifolia Vahl) under conditions of substrate saturation and normal watering on 16 July 2015

\begin{tabular}{lccccccc}
\multicolumn{1}{c}{ Treatment } & N & Mean & Median & Minimum & Maximum & Variance & Std. Dev. \\
\hline Saturation & 120 & 17.8 & 16.8 & 7.8 & 32.6 & 34.9 & 5.9 \\
Watering & 115 & 18.3 & 17.1 & 3.1 & 65.1 & 89.6 & 9.5 \\
\hline
\end{tabular}

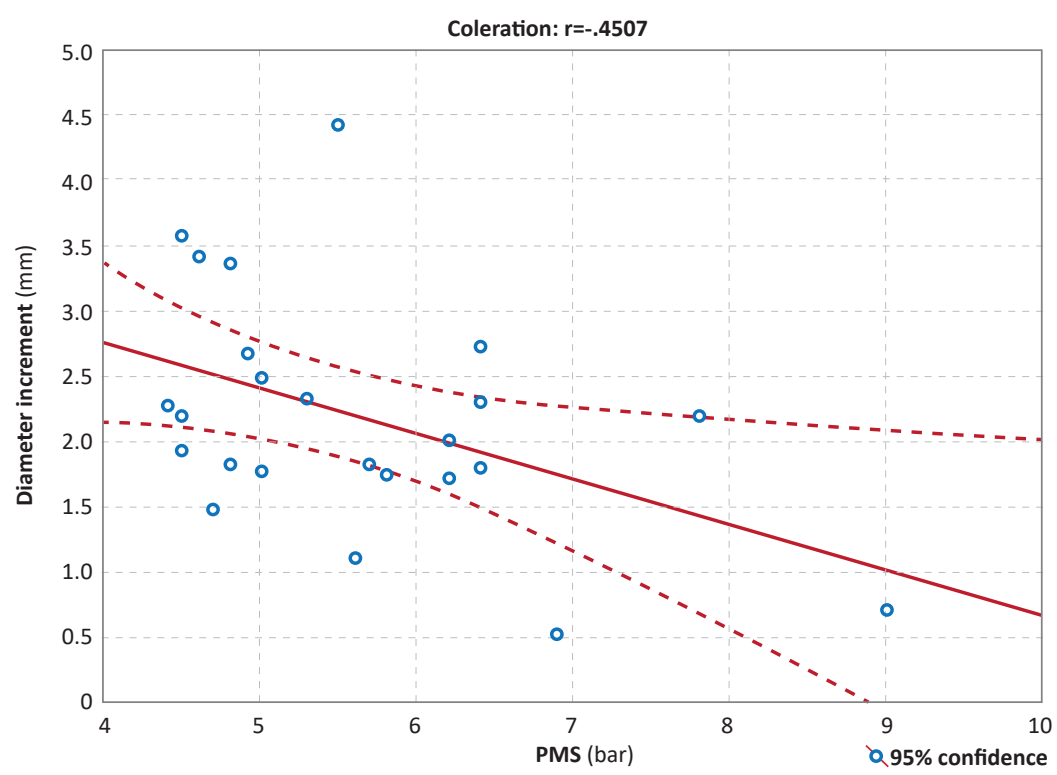

FIGURE1. Correlations between diameter increment $(\mathrm{mm})$ of container seedlings of narrow-leaved ash under conditions of substrate saturation and water potential (bar) on 16 July 2015 
period (April - September) manifests a considerable decrease in height increment and biomass [13, 14].

Our research showed that the height increment of narrow-leaved ash seedlings growing in saturated substrates was by $62 \mathrm{~mm}$ better on average as compared to the seedlings that received normal quantities of water. Evidently, the European ash and narrow-leaved ash are species with diverse ecological requirements.

The development of plant hypertrophy as a morphological response to flood conditions in which plant aeration is increased [15] was recorded in the species Fraxinus excelsior L. [13]. This phenomenon was observed

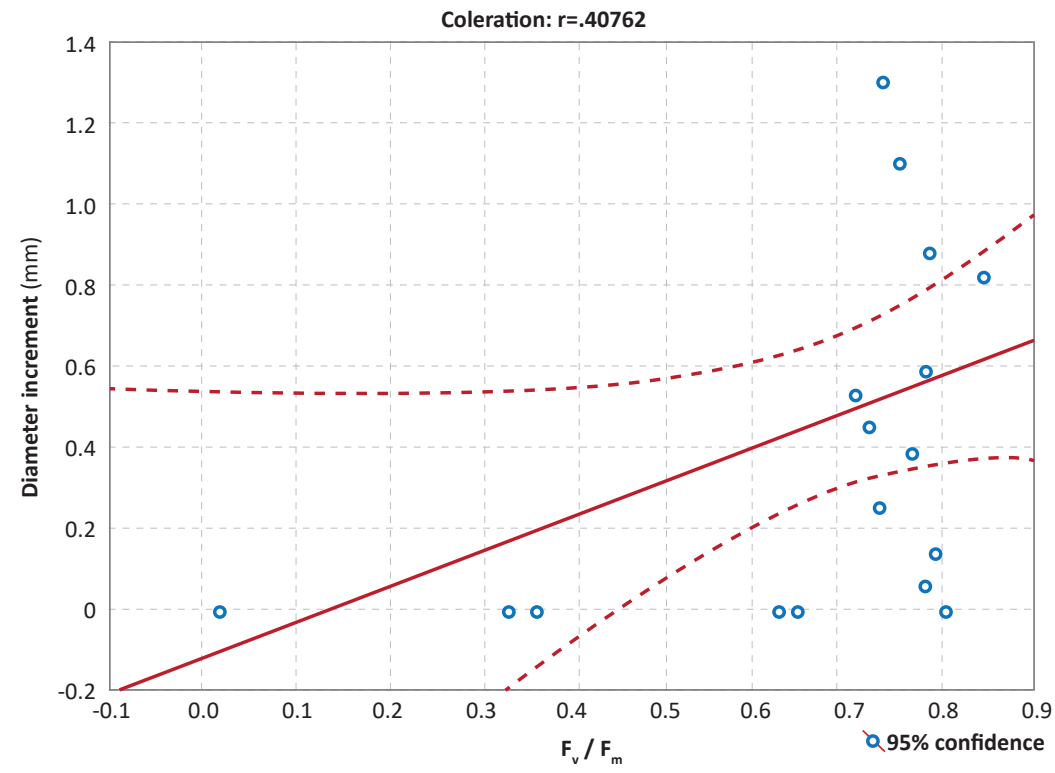

FIGURE 2. Correlations between diameter increment $(\mathrm{mm})$ of container seedlings of narrow-leaved ash and the maximum quantum yield of photosystem II $\left(F_{v} / F_{m}\right)$ in normally watered seedlings on 16 July 2015

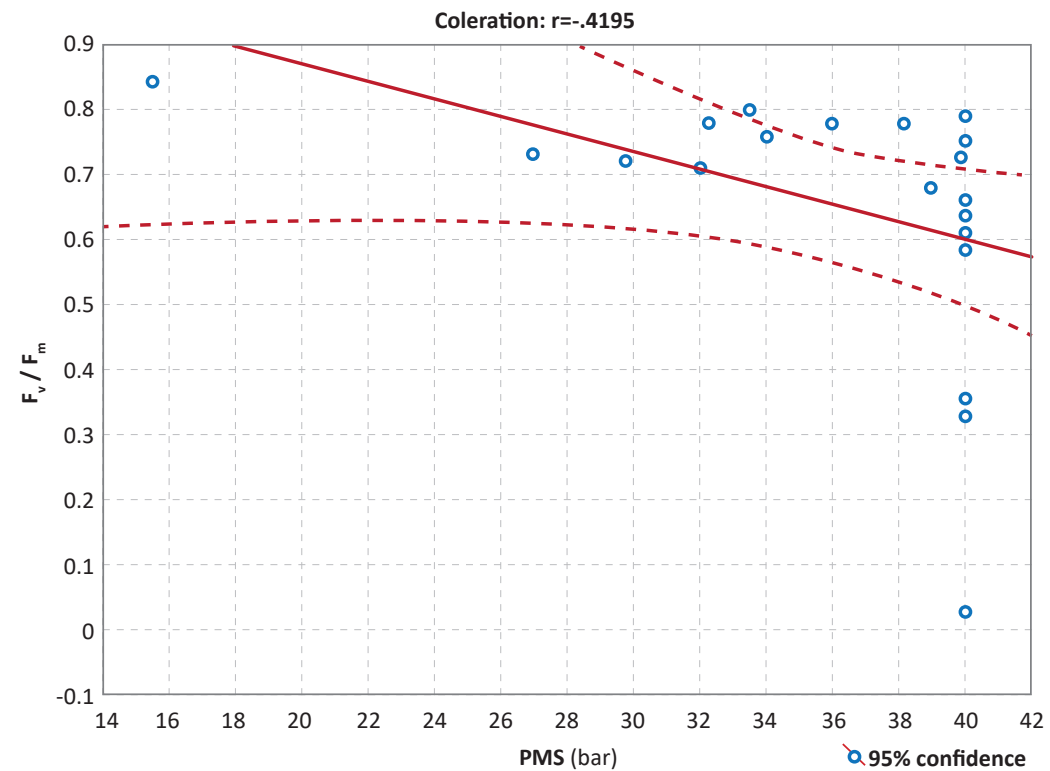

FIGURE 3. Correlations between the maximum quantum yield of photosystem II $\left(F_{v} / F_{m}\right)$ and water potential (bar) in normally watered seedlings on 16 July 2015 
in the provenance "Rhine" from alluvial stands, but not in the provenances "Alb" and "BFor", which indicates specific provenance adaptations to site conditions [12]. Morphological and anatomic adaptations of species of floodplain forest to floods are discussed by [16-19]. Our research confirmed what was mentioned above. Diameter increment of seedlings growing in saturated substrates was higher by $1.81 \mathrm{~cm}$ on average in relation to seedlings that were watered normally.

The plant root is in the soil with a high water potential, while the above-ground parts are surrounded by air, whose water potential is low. The existing water potential gradient enables transpiration course by which water is transported from the soil through the plant with no energy consumption and is released in the atmosphere. If low pressure ( 3 bars or $45 \mathrm{psi}$ ) is sufficient for water to emerge on the surface of a leaf cross-section, then the plant is under a relatively low water stress (high water potential) and probably has enough water for growth processes. If a pressure of 20 bars is needed for water to appear on the surface of the cut, the water stress is relatively high (low water potential). Water potential values differ from species to species. Succulents or young shoots may wilt at a low pressure of 7-8 bars, and certain physiological processes, such as photosynthesis, may be decreased at pressures lower than $10-15$ bars. In our research, the average seedling water potential under substrate saturation was 5.6 bars (4.4 - 9.0 bars), and in normal watering conditions it was 36.1 bars (15.5-40 bars and higher). At 10 plants (45.45\%), thepressure could not be taken due to the instrument being limited to 40 bars.

Photosynthesis is a very sensitive and early indicator of plant vitality $[20,21]$. One of the first responses of a plant to unfavourable conditions is reflected in lower photosynthetic efficiency and in inhibitions of different molecular mechanisms. In this sense, the analysis of chlorophyll fluorescence is an excellent tool for determining different photosynthetic parameters that can be used for photosynthesis optimisation and control in field cultures. Chlorophyll fluorescence provides useful information about the photosynthetic efficiency under abiotic stresses [22]. Chlorophyll fluorescence analysis is a powerful tool for the study of species under normal and stressful conditions [23, 24]. Chlorophyll fluorescence can be used to assess plant vitality and stress. The parameter $F_{v} / F_{m}$ is calculated from the minimum fluorescence value $\left(F_{0}\right)$ and the maximum value $\left(F_{m}\right)$ using the formula $\left(F_{m}-F_{0}\right) / F_{m}$ It reflects the efficiency of electron transfer in photosystem II and is used as an indicator of the success of photosynthetic efficiency.

The difference between maximum and minimum fluorescence is called variable fluorescence $\left(F_{v}\right)$. An optimum yield of photosystem II, $F_{v} / F_{m}$ is calculated from these data. This ratio represents a measure of the potential maximum quantum yield of photosystem II.

There are photosystems I and II. In the centre of

TABLE 5. Descriptive statistics of substrate temperature $\left({ }^{\circ} \mathrm{C}\right)$ and volumetric substrate moisture (\%)

\begin{tabular}{|c|c|c|c|c|}
\hline Conditions & Mean & Min. & Max. & Std. Dev. \\
\hline \multicolumn{5}{|c|}{ Substrate temperature $\left({ }^{\circ} \mathrm{C}\right)$} \\
\hline Drought & 20.7 & 10.4 & 34.6 & 4.5 \\
\hline Saturation & 19.6 & 12.0 & 27.9 & 3.2 \\
\hline Watering & 20.1 & 9.1 & 32.8 & 4.8 \\
\hline \multicolumn{5}{|c|}{ Volumetric substrate moisture (\%) } \\
\hline Drought & 19.8 & 6.1 & 33.6 & 7.2 \\
\hline Saturation & 41.3 & 36.7 & 148.8 & 16.1 \\
\hline Watering & 22.8 & 6.6 & 34.2 & 8.1 \\
\hline
\end{tabular}

TABLE 6. The comparison of mean values of substrate temperature and volumetric substrate moisture in different conditions

\begin{tabular}{lcc} 
& \multicolumn{2}{c}{ Microclimatic elements } \\
\cline { 2 - 3 } Conditions & Substrate temperature $\left({ }^{\circ} \mathrm{C}\right)$ & Vol. substrate moisture $(\%)$ \\
\hline Drought & $20.7 \pm 4.59^{\mathrm{a}}$ & $19.8 \pm 7.2^{\mathrm{a}}$ \\
Saturation & $19.6 \pm 3.2^{\mathrm{b}}$ & $41.3 \pm 16.1^{\mathrm{b}}$ \\
Watering & $20.1 \pm 4.8^{\mathrm{c}}$ & $22.8 \pm 8.1^{\mathrm{c}}$ \\
\hline
\end{tabular}

\footnotetext{
$a, b, c$ Values within the column marked with a different letter significantly differ $(p<0.05)$. Values are presented as the mean $\pm s t d$. dev.
} 
photosystem I there is a chlorophyll molecule which has maximum absorption at a wavelength of $700 \mathrm{~nm}$, while a chlorophyll molecule in photosystem II has maximum absorption at a wavelength of $680 \mathrm{~nm}$ [25].

Chlorophyll fluorescence can be used to assess vitality and stress of several cultivars, as well as analyze different cultivars in terms of their response to stress factors. Franić et al. [26] state that in general, the lowest Fv/Fm values were measured in treatments with insufficient water $/ 5 \mathrm{mg} \mathrm{Cd}$ in the soil, and the highest in treatments with sufficient water without cadmium, which points to the negative effect of a combination of water stress and cadmium-induced stress. Identical results were obtained by our studies (without cadmium). The average value of the maximum quantum yield of photosystem II $\left(F_{v} / F_{m}\right)$ in seedlings treated by substrate saturation was 0.82 , and in seedlings that were watered normally it was 0.65 . In the majority of plant species, the potential maximum quantum yield of photosystem $\mathrm{II}$ is about 0.83 . The maximum quantum yield of photosystem II in watered seedlings was lower by 0.17 on average, which indicates that the seedlings were under a stronger physiological shock. The chlorophyll metre works by emitting light at a wavelength of $653 \mathrm{~nm}$ (the red part of the solar spectre) and of $931 \mathrm{~nm}$ (the infrared part of the solar spectre) through the leaf mesophyll filled with chloroplasts that contain chlorophyll. The chlorophyll content index (CCI) is obtained on the basis of the relative quantity of the emitted, i.e. absorbed light by the chlorophyll. Measurements of the chlorophyll content index during the vegetation period can help us determine the optimal time for fertilization and the application of other pomotechnical treatments in nurseries, cultures or clonal seed orchards, thus improving the quantity and quality of the increment or seed yield. No statistically significant differences were found in the total chlorophyll content index $(\mathrm{CCl})$ in seedling leaf mesophyll under substrate saturation and normal watering conditions.

Seedling diameter increment decreases with an increase in water potential values, as stated by Jaeger [12]. At normal watering, seedling diameter increment increases as the maximum quantum yield of photosystem II increases. An increase in the water potential value of seedlings under normal watering decreases the maximum quantum yield of photosystem II.

Consecutive dry years have a significant impact on the dieback of pedunculate oak and narrow-leaved ash, which are hygrophytes in terms of their ecological requirements for water. As for floods, the only difference is that pedunculate oak's dieback is affected by the occurrence of floods, whereas narrow-leaved ash's dieback is affected by the absence of floods. Here, the issue is probably the duration of flooding. Pedunculate oak cannot tolerate long-lasting floods, unlike narrow-leaved ash which is a more hygrophytic forest tree species. Narrow-leaved ash is a distinct hygrophyte capable of tolerating stagnant water on the soil surface, the surplus of carbon dioxide and the lack of oxygen in swampy soils. Of importance is the fact that narrow-leaved ash cannot thrive under swampy conditions when water stagnates on the soil throughout the vegetation period. Changes in the onset and size of floods are the consequence of climate change and global warming. Large-scale floods will occur with rising frequency. There will be fewer small-scale floods [27]. Changes in climate that are expected in lowland Croatia will probably bring about a rise in air temperatures and a drop in precipitation quantities. The current status of hydrological conditions, which severe droughts occurring in the past several decades have changed significantly, are becoming ever more unfavourable for the survival of lowland forests with regard to their water requirements and the dependence of lowland species on groundwater [28]. Among all studied climatic elements and indices, it is lower precipitation quantities that have had a significant effect on the dieback of narrow-leaved ash [9].

The most favourable temperatures for the growth and development of an organism are those at which all the processes are best coordinated [29]. In terms of the requirements for air temperature and soil, narrow-leaved ash belongs to the eurithermal tree species, which are hardly susceptible to winter cold and summer heat, but highly susceptible to winter frost.

\section{CONCLUSIONS}

Containerized narrow-leaved ash seedlings saturated with water for 72 days showed a better morphologicalphysiological status than the seedlings that received normal quantities of water.

A statistically significant difference was confirmed in the morphological status of seedlings under conditions of substrate saturation and normal watering. Seedlings growing in saturated substrates attained bigger height increment by $62 \mathrm{~mm}$ and bigger diameter increment by1.81 $\mathrm{mm}$ on average, compared to seedlings that were watered normally.

A statistically significant difference was obtained in the physiological status of seedlings. The water potential of watered seedlings needed pressure that was higher by 30.5 bars in order for water to appear on the surface of the leaf cross-section. Seedlings growing in saturated substrates were under a low water stress or high water potential compared to watered seedlings, in which a low water potential or high water stress was observed. Photosynthetic efficiency ofwatered seedlings had a lower maximum quantum yield of photosystem II by 0.17 on average, which indicates that they were exposed to a bigger physiological shock.

Seedlings of narrow-leaved ash as a hygrophytic tree species do not tolerate dry conditions and no watering. 


\section{REFERENCES}

1. ANIĆ । 1997 Regeneration of narrow-leaved ash stands (Fraxinus angustifolia Vahl) in central Croatia (in Croatian with English summary). Glasnik za šumske pokuse 34: 1-40

2. PRPIĆ B 1971 Zakorjenjivanje hrasta lužnjaka, poljskog jasena i crne johe u Posavini (in Croatian). Savjetovanje o Posavini pp 347-352

3. TIKVIĆ I, SELETKOVIĆ Z 2004 Dieback and disturbance of the stability of the lowland forest ecosystems. Bulletin of Lonjsko Polje Nature Park 6 (2): 58-67. URL: http:// www.pp-lonjsko-polje.hr/new/media/publikacije/Bilten Vol 06 No 2 2004.pdf (10 April 2016)

4. PRPIĆ B, SELETKOVIĆ Z, ŽNIDARIĆ G 1994 Ecological and biological causes dieback of pedunculate oak (Quercus robur L.) in lowland Turopoljski lug (in Croatian with English summary). Glasnik za šumske pokuse 30: 193-222

5. PRPIĆ B, ANIĆ I 2000 The role of climatic and hydraulic operations in the stability of the pedunculate oak (Quercus robur L.) stands in Croatia. Glasnik za šumske pokuse 37: 229-239

6. MATIĆ S 2000 Oak forests (Quercus sp.) in Croatia. Glasnik za šumske pokuse 37: 5-13

7. TIKVIĆ I, PERNAR N, SELETKOVIĆ Z, UGARKOVIĆ D, MIKAC S 2008 Promjene hidroloških uvjeta u nizinskim šumskim ekosustavima i mogućnost njihovog unaprjeđenja. Presenation at the scientific symposium "Forests of Pedunculate Oak in Changed Site and Management Conditions". Croatian Academy of Sciences and Arts, Zagreb, Croatia

8. STATSOFT, INC. 2003 STATISTICA for Windows. Tulsa: StatSoft, Inc.

9. HRAŠOVEC B, MARGALETIĆ J, DIMINIĆ D, DRVODELIĆ D, UGARKOVIĆ D, MIKAC S, FRANJEVIĆ M, VUCELJA M 2015 The second periodical report of the project "Ecology and regeneration of the lowland forests in Posavina". University of Zagreb, Faculty of Forestry, Zagreb, Croatia, $90 \mathrm{p}$

10. SPRINGER OP, PEVALEK-KOZLINA B 1997 Rast i razvitak biljaka. In: Springer OP (ed) Biologija 3: Fiziologija bilja. Profil, Zagreb, Croatia, pp 238-239

11. ARMSTRONG W, BRÄNDLE R, JACKSON MB 1994 Mechanisms of flood tolerance in plants. Acta Bot Neerl 43 (4): 307-358. DOI: http://dx.doi. org/10.1111/j.1438-8677.1994.tb00756.x

12. JAEGER C 2008 Ecophysiological studies on the flood tolerance of common ash (Fraxinus excelsior L.) - impact of root-zone hypoxia on central parameters of $\mathrm{C}$ metabolism. $\mathrm{PhD}$ thesis, Faculty of Forest and Environmental Sciences, Albert-Ludwigs-Universit at Freiburg imBreisgau, Germany, $184 \mathrm{p}$

13. FRYE J, GROSSE W 1992 Growth responses to floodingand recovery of deciduous trees. Zeitschrift für Naturforschung 47c: $683-689$

14. IREMONGER S F, KELLY D L 1988 The responses of four Irish wetland tree species to raised soil water levels. New Phytol 109 (4): 491-497. DOI: http://dx.doi. org/10.1111/i.1469-8137.1988.tb03725.x

15. KAWASE M 1981 Anatomical and morphological adaptation of plants to waterlogging. HortScience 16 (1): 30-34

16. CRAWFORD RMM 1967 Alcohol dehydrogenase activity in relation to flooding tolerance in roots. J Exp Bot 18 (3): 458464. DOI: http://dx.doi.org/10.1093/jxb/18.3.458

17. NAIDOO G, MCKEE KL, MENDELSSOHN IA 1992 Anatomical and metabolic responses to waterlogging and salinity in Spartina alterniora and S. patens (Poaceae). Am J Bot 79 (7): 765-770
18. VARTAPETIAN B, ANDREEVA N, GENEROZOVA P, POLYAKOVA I, MASLOVA P, DOLGIKH I, STEPANOVA U 2003 Functional electron microscopy in studies of plant response and adaptation to anaerobic stress. Ann Bot-London 91 (2): 155-172. DOI: http://dx.doi.org/10.1093/aob/mcf244

19. BENZ BR, RHODE JM, CRUZAN MB 2007 Aerenchyma development and elevated alcohol dehydrogenase activity as alternative responses to hypoxic soils in the Piriqueta caroliniana complex. Am J Bot 94 (4): 542-550. DOI: http:// dx.doi.org/10.3732/ajb.94.4.542

20. KRAUSE GH, WEISS E 1991 Chlorophyll fluorescence and photosynthesis: the basics. Annu Rev Plant Phys 42: 313-349. DOI: http://dx.doi.org/10.1146/annurev. pp.42.060191.001525

21. SCHREIBER U, BILGER W, NEUBAUER C 1994 Chlorophyll fluorescence as a non-destructive indicator for rapid assess assessment of in vivo photosynthesis. In: Schulze ED, Caldwell MM (eds). Ecophysiology of photosynthesis. Springer, Berlin, Germany, pp 49-70

22. BRESTIC M, ZIVCAK M 2013 PSII fluorescence techniques for measurement of drought and high temperature stress signal in plants: protocols and applications., In: Rout GR, Das AB (eds) Molecular stress physiology of plants. Springer, Dordrecht, Netherlands, pp 87-131. DOI: http:// dx.doi.org/10.1007/978-81-322-0807-5 4

23. STRASSER RJ, SRIVASTAVA A, TSIMILLI-MICHAEL M 2000 The fluorescence transient as a tool to characterize and screen photosynthetic samples. In: Yunus M, Pathre $\mathrm{U}$, MohantyP (eds) Probing Photosynthesis: Mechanism, Regulation and Adaptation. Taylor and Francis, London, UK, pp 443-480

24. REDDY AR, STRASSER RJ 2000 Probing the vitality of plants by the JIP-test, a novel non-invasive phenotypic screening technique for performance under water-limited conditions. In: Ribaut, JM, Poland D (eds) Molecular approaches for the genetic improvement of cereals for stable production in water-limited environments. A strategic planning. Workshop held at CIMMYT, El Batan, Mexico, 21-25 June 1999. Mexico D.F. CIMMYT, pp 90-91

25. SPRINGER OP, PEVALEK-KOZLINA B 1997 Fotosinteza. In: Springer OP (ed) Biologija 3: Fiziologija bilja. Profil, Zagreb, Croatia, pp 220-225

26. FRANIĆ M, MAZUR M, ANTUNOVIĆ J, BEGOVIĆ L, ANDRIĆ L, JAMBROVIĆ A, ZDUNIĆ Z, LEDENČAN T, et al., 2015 Chlorophyll fluorescence parameters of three maize genotypes challenged by water andcadmium stress. 50th Croatian and 10th International Symposium on Agriculture, pp 104

27. ROLF OLSEN J 2006 Climate change and floodplain management in the United States.Climatic Change 76 (3): 407-426. DOI: http://dx.doi.org/10.1007/s10584-0059020-3

28. VRBEK B, PILAŠ I, PERNAR N 2011 Observed Climate Change in Croatia and its impact on hydrology of lowlands. In: Bredemeier M, Cohen S, Godbold DL, Lode E, PichlerV, Schleppi P (eds) Forest Management and Water Cycle. Springer, Netherlands, pp141-162. DOI: http://dx.doi. org/10.1007/978-90-481-9834-4 8

29. LUKŠA Ž, MIKULIĆ S 2009 Gibanja biljnog organizma. In: Ćorić S (ed) Život 3: Fiziologija bilja. Školska knjiga, Zagreb, Croatia, pp 186-187 